\title{
Synthesis and characterization of novel 2, 2'- bipyrimidine fluorescent derivative for protein binding
}

\author{
Vikas S Padalkar, Vikas S Patil and N Sekar
}

\begin{abstract}
Background: Fluorescent dyes with biocompatible functional group and good fluorescence behavior are used as biosensor for monitoring different biological processes as well as detection of protein assay. All reported fluorophore used as sensors are having high selectivity and sensitivity but till there is more demand to synthesized new fluorophore which have improved fluorescence properties and good biocompatibility.

Results: Novel 4, 4'-(1, 1'-(5-(2-methoxyphenoxy)-[2, 2'-bipyrimidine]-4, 6-diyl)bis(1H-pyrazol-3, 1-diyl)) dianiline fluorescent dye was synthesized by multistep synthesis from 2-phenylacetonitrile, 2-chloropyrimidine and 2methoxyphenol. This dye has absorption at $379 \mathrm{~nm}$ with intense single emission at $497 \mathrm{~nm}$ having fairly good quantum yield (0.375) and Stokes shift. The intermediates and dye were characterized by FT-IR, ${ }^{1} \mathrm{H}$ NMR, ${ }^{13} \mathrm{C}$ NMR and Mass spectral analysis. The pyrazole bipyrimidine based fluorescent dye possessing two amino groups suitable for binding with protein is reported. Its utility as a biocompatible conjugate was explained by conjugation with bovine serum albumin. The method is based on direct fluorescence detection of fluorophore-labelled protein before and after conjugation. Purified fluorescent conjugate was subsequently analyzed by fluorimetry. The analysis showed that the tested conjugation reaction yielded fluorescent conjugates of the dye through carbodiimide chemistry.

Conclusion: In summery synthesized fluorophore pyrazole-bipyrimidine has very good interaction towards protein bovine serum albumin and it acts as good candidate for protein assay.
\end{abstract}

\section{Background}

Protein recognition by synthetic molecules is a challenging endeavour, since these materials must bind to a large relatively flat surface domain and recognize a unique distribution of amino acid residues of varying charge, size and shape [1]. Identification and quantification of specific proteins is an important issue in medical and clinical research as many diseases have a specific change in protein expression [2-5]. The most commonly used technique in clinics is enzyme-linked immunosorbent assay (ELISA), which requires specific storage of active enzymes and tedious protein modification [6].

Different strategies have been developed to simplify the detection procedure, which involve specific metal coordination, epitope-docking on miniature proteins, aptamer

\footnotetext{
* Correspondence: n.sekar@ictmumbai.edu.in

Department of Intermediates and Dyestuff Technology, Institute of Chemical Technology, N. P. Marg, Matunga, Mumbai - 400 019, India
}

selection, non-natural peptide isosteres, functionalized platforms, secondary structure mimetics, molecular imprinting and receptors embedded in lipid layers. Recognition of protein binding or change in the structure is detected with the help of fluorescence [7], electrochemistry [8], Raman spectroscopy [9], chemiluminescence [10], flow cytometry [11] and micro fluidic methods [12]. However, most of these methods require sophisticated instrumentation and proficient manipulation, which highly motivated the development of simple and reliable protein detection systems.

In general, the preferred fluorescent labels should have high fluorescence quantum yields and retain the biological activities of the parent unlabeled biomolecules. A fluorescent dye can be attached to a peptide at a specific point through a covalent bond depending on the sequence of peptide. The linkage between dye and peptide is a covalent bond, which is stable and not 
destructive under most biological conditions. In some cases, a functional linker is introduced between dye and peptide to minimize the alteration of peptide biological activity. For all the peptide labeling, the dye needs to be attached at a defined position: $\mathrm{N}$-terminus, C-terminus, or in the middle of a sequence. Several fluorescence probes have been reported in the literature to investigate biological process through fluorescence measurements [13-15]. For use as reporter molecules in biological systems many organic dyes have been studied, like coumarin derivatives [16], fluorescein isothiocyanates $[17,18]$, anthracene derivatives [19] and $\beta$-naphthol [20].

Amine-containing dyes are used to modify peptides using water-soluble carbodiimides (such as EDC) to convert the carboxy groups of the peptides into amide groups. Either NHS or NHSS may be used to improve the coupling efficiency of EDC-mediated protein-carboxylic acid conjugations. A large excess of the amine-containing dyes is usually used for EDC-mediated bioconjugations in concentrated large peptide solutions at low $\mathrm{pH}$ to reduce intra- and inter-protein coupling residues, a common side reaction.

The spectral changes observed on the binding of fluorophores with proteins are an important tool for the investigations of the topology of binding sites, conformational changes and characterization of substrate to ligand binding. Besides, determination of protein quantity in biological liquids is of great importance in biology and medicine and fluorescent probes are successfully applied for this approach [21].

As a part of our ongoing research to develop novel materials for high tech applications [22-24], here we report the synthesis, characterization and photophysical properties of a novel fluorescent biocompatible fluorescent probe for protein assay having a pyrazole bipyrimidine framework. The novel fluorophore was prepared by multistep synthesis from 2-chloropyrimidine, phenylacetonitrile and 2-methoxyphenol.

\section{Results and Discussion}

Z-2-(4'-Nitrophenyl)-3-hydroxypropenal 5 was prepared form phenylacetonitrile by nitration, hydrolysis followed by Vilsmeier Hacck formylation. The amidine $\mathbf{8}$ was prepared in two steps from 2-chloropyrimidine $\mathbf{6}$. Reaction of dimethyl chloromalonate $\mathbf{1 0}$ with guaiacol $\mathbf{9}$ afforded malonate 11. Pyrimidinedione 12 was then constructed via an amidine $\mathbf{8}$ and malanoate $\mathbf{1 1}$ condensation. The pyrimidinedione $\mathbf{1 2}$ was converted to the dichloropyrimidine 13 with phosphorous oxychloride, reaction of hydrazine hydrate with dichloropyrimidine $\mathbf{1 3}$ yielded the desired 4, 6-dihydrazinyl-5-(2-methoxyphenoxy)-2, 2'-bipyrimidine 14. Intermediate 4, 6-dihydrazinyl-5-(2methoxyphenoxy)-2, 2'-bipyrimidine 14 reacted with an intermediate Z-2-(4'-nitrophenyl)-3-hydroxypropenal $\mathbf{5}$ which was prepared from phenyl acetonitrile through multistep process yielded 5-(2-methoxyphenoxy)-4, 6-bis (3-)4-nitrophenyl)-1H-pyrazole-1-yl)-2, 2'-bipyrimidine fluorophore 15 contains nitro group which is not biocompatible. The basic requirements for fluorophore to be good candidate are that it should contain biocompatible group for binding, high photostability with good quantum yield. 5-(2-Methoxyphenoxy)-4, 6-bis(3-)4nitrophenyl)-1H-pyrazole-1-yl)-2, 2'-bipyrimidine 15 was further reduced to 4, 4'-(1, 1'-(5-(2-methoxyphenoxy)-[2, 2'-bipyrimidine]-4, 6-diyl)bis(1H-pyrazole-3, 1-diyl) ) dianiline 16 by using $\mathrm{Pd} / \mathrm{C}$ and hydrazine hydrate as shown in Scheme 1. The structure of the compounds was confirmed by FT-IR, ${ }^{1} \mathrm{H}$ NMR and Mass spectral analysis.

The synthesized novel heterocyclic dye $\mathbf{1 6}$ is fluorescent in solution when irradiated with UV-light and framework contain biocompatible free amino groups which were further explored for labelling with protein bovine serum albumin. The dye had absorption at $379 \mathrm{~nm}$ accompanied by intense single emission in the range $497 \mathrm{~nm}$ with good quantum yield (0.375). The dye was conjugated with protein bovine serum albumin (BSA) through carbodiimide chemistry between the surface terminated negatively charged carboxylate groups $\left(-\mathrm{COO}^{-}\right)$of

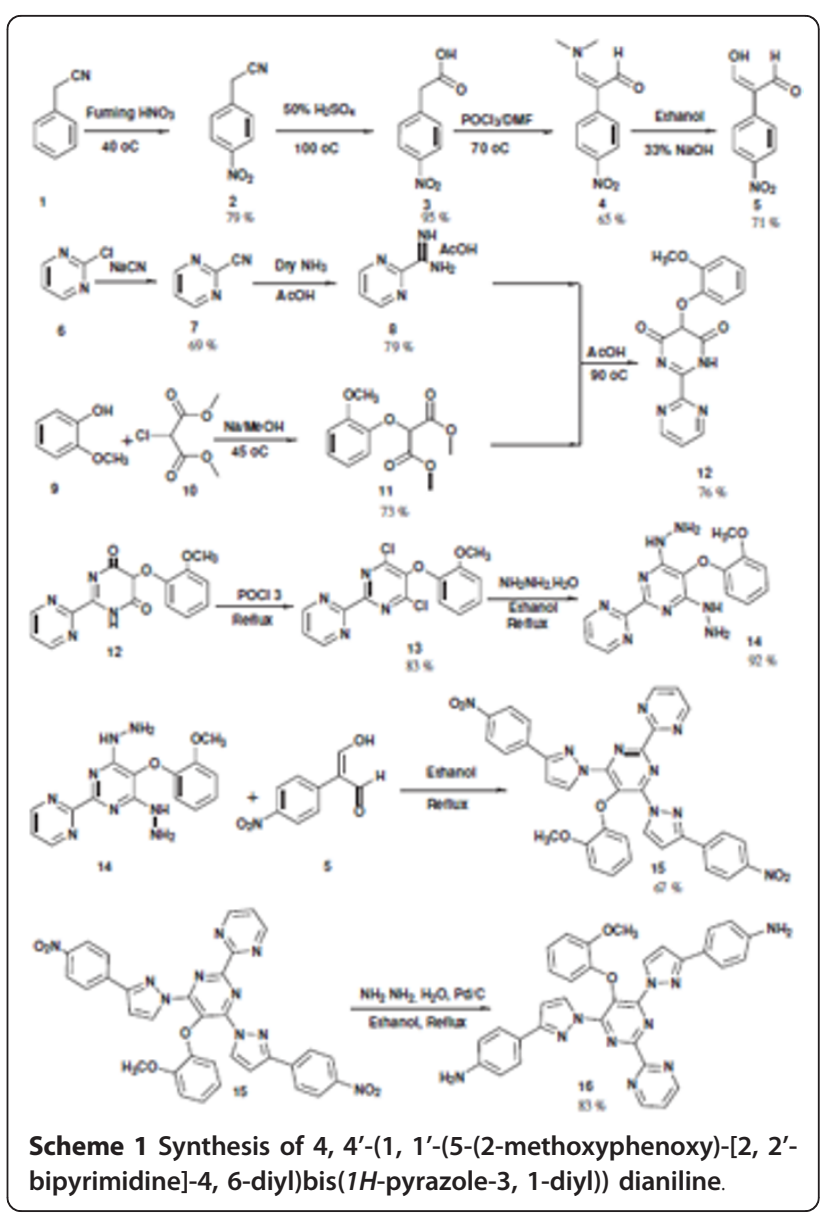


protein and the positively charged amino groups $\left(-\mathrm{NH}_{3}{ }^{+}\right)$ of the fluorophore. This interaction between functionalized amino groups with protein molecule was investigated using fluorescence spectroscopy showing the fluorescence quenching of the fluorophore after the conjugation with protein which is due to covalent bond formation between carboxylate group of protein and amino group of fluorophore. In order to warrant an efficacious label the unbound fluorophore was efficiently removed from unconjugated one by dialysis in phosphate buffer solution at $\mathrm{pH}$ 7. Conjugation of fluophore with protein was analyzed by using fluorescence emission analysis. Fluorescence study showed that novel fluorescent compound has very good interaction towards the biomolecules.

\section{Photophysical Properties}

An effective fluorescent dye for biological application has to present a good fluorescent intensity, high quantum yield and high photostability. Quantum yield of dye 16 was determined by using anthracene as standard. The absorption and emission characteristic of standard as well as compound $\mathbf{1 6}$ were measured at different concentration (2, 4, 6, 8 and $10 \mathrm{ppm}$ level). Absorbance intensity values were plotted against emission intensity values, a linear plot was obtained. Gradients were calculated for dye $\mathbf{1 6}$ and for standard. All the measurements were done by keeping the parameters constant such as same solvent and constant slit width. Relative quantum yield of dye 16 was calculated by using Formula 1[25].

Gradient of standard (Additional file 1) and gradient of unknown (Additional file 1) was calculated for quantum yield calculation of novel compound $\mathbf{1 6}$ is described in Table 1 respectively. By putting value of gradients in Formula 1, quantum yield were calculated for dye by taking anthracene as standard (Quantum yield of anthracene in ethanol solution is 0.270). Quantum yield of the dye in ethanol is 0.375 .

Formula 1: Relative fluorescence quantum yield

$$
\Phi x=\boldsymbol{\Phi}_{S T}\left(\operatorname{Grad}_{X} / \operatorname{Grad}_{S T}\right)\left(\eta^{2} x / \eta^{2}{ }_{S T}\right)
$$

Table 1 Quantum yield calculation of compound 16

\begin{tabular}{ll}
\hline Gradient Anthracene & Gradient of Compound 16 \\
\hline $\mathrm{Gd}_{\text {ST }}=\mathrm{Y}_{2}-\mathrm{Y}_{1} / \mathrm{X}_{2}-\mathrm{X}_{1}$ & $\mathrm{Gd}_{16}=\mathrm{Y}_{2}-\mathrm{Y}_{1} / \mathrm{X}_{2}-\mathrm{X}_{1}$ \\
$\mathrm{Gd}_{\mathrm{ST}}=(148.08-45.85) /(0.405-0.078)$ & $\mathrm{Gd}_{16}=(207.02-110.00) /$ \\
& $(0.530-0.307)$ \\
$\mathrm{Gd}_{\mathrm{ST}}=102.23 / 0.327$ & $\mathrm{Gd}_{16}=97.02 / 0.223$ \\
$G d_{\text {ST }}=312.62$ & $\mathrm{Gd}_{16}=435.06$ \\
\hline$\Phi_{16}=(435.06 / 312.6) \Phi_{\text {ST }}$ & \\
$\Phi_{16}=(1.391)(0.27)$ & \\
$\Phi_{16}=0.375$ &
\end{tabular}

Where: $\boldsymbol{\Phi}_{X}=$ Quantum yield of unknown sample

$\boldsymbol{\Phi}_{S T}=$ Quantum yield of standard used

$\operatorname{Grad}_{\mathrm{X}}=$ Gradient of unknown sample

$\operatorname{Grad}_{\mathrm{X}}=$ Gradient of standard used

$\eta_{S T}^{2}=$ Refractive index of solvent for standard sample

$\eta_{X}^{2}=$ Refractive index of solvent for sample

\section{Protein Binding with Dye 16}

Binding of dye $\mathbf{1 6}$ with protein was confirmed by change in the fluorescence wavelength before and after conjugation. Observed difference between fluorescence emission after conjugation and before conjugation is $30 \mathrm{~nm}$. Measurement was performed at very low concentration of dye $(0.001,10 \mathrm{ppm}$ concentration) Figure 1 . The change in emission wavelength after conjugation is due to formation of covalent linkage between carboxy group of protein and amino group of dye.

This dye 16 was proposed to bind with carboxylate group on protein surface. Accordingly, the binding number of dye per protein molecules depends on the accessible number of carboxylate groups on each type of protein. The conjugation extent of bovine serum albumin with fluorophore $\mathbf{1 6}$ at various concentration of dye was studied. The amount of dye bound to protein increased gradually as the dye concentration increased from 0.001 to 0.01 . At higher dye concentrations the fluorescence intensity became steady, probably due to saturated binding between dye and protein Figure 2 .

Fluorescence emission properties of conjugated dyeprotein were also studied by varying the amount of protein by keeping dye concentration constant. It was observed that there is no change in emission intensity of dye-protein conjugate at various protein concentrations Figure 3.

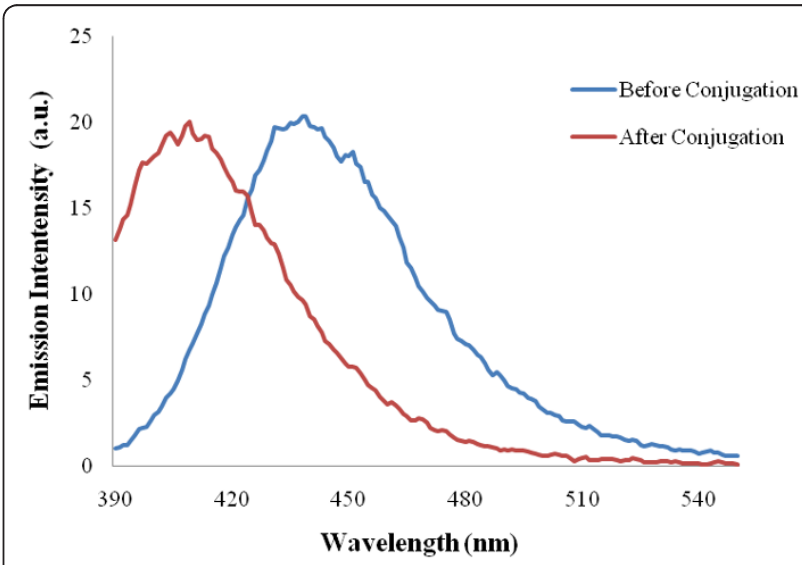

Figure 1 Fluorescence emission of dye before and after binding with protein BSA. 


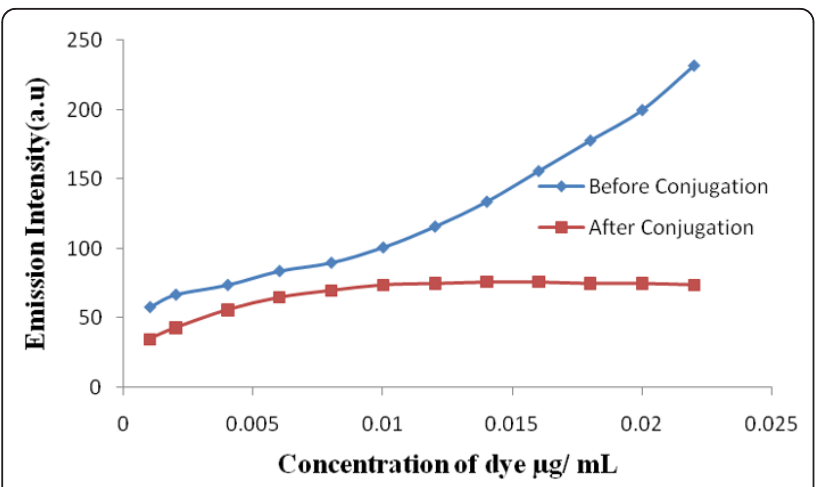

Figure 2 Fluorescence emission of fluorophore 16 before and after conjugation with protein bovine serum albumin (BSA) with various amount of dye.

\section{Experimental}

\section{General Information}

\section{Biological and chemical materials}

All commercial reagents and solvents were purchased from s d fine chemicals (India) and were used without purification. Bovine Serum Albumin (BSA) was purchased from Sigma Aldrich. Column chromatography was performed using silica gel 60-120 mesh size. The reaction was monitored by TLC using on $0.25 \mathrm{~mm}$ EMerck silica gel $60 \mathrm{~F}_{254}$ precoated plates, which were visualized with UV light.

\section{Instruments}

The FT-IR spectra were recorded on Perkins-Elmer 257 spectrometer using $\mathrm{KBr}$ discs. ${ }^{1} \mathrm{H}$ NMR and ${ }^{13} \mathrm{C}$ NMR spectra were recorded on VARIAN $400 \mathrm{MHz}$ and 100 $\mathrm{MHz}$ instrument using TMS as an internal standard. Mass spectra were recorded on Finnigan mass spectrometer. The visible absorption spectra of the compounds were recorded on a Spectronic Genesys 2 UV-Visible spectrometer. Fluorescence emission analysis and

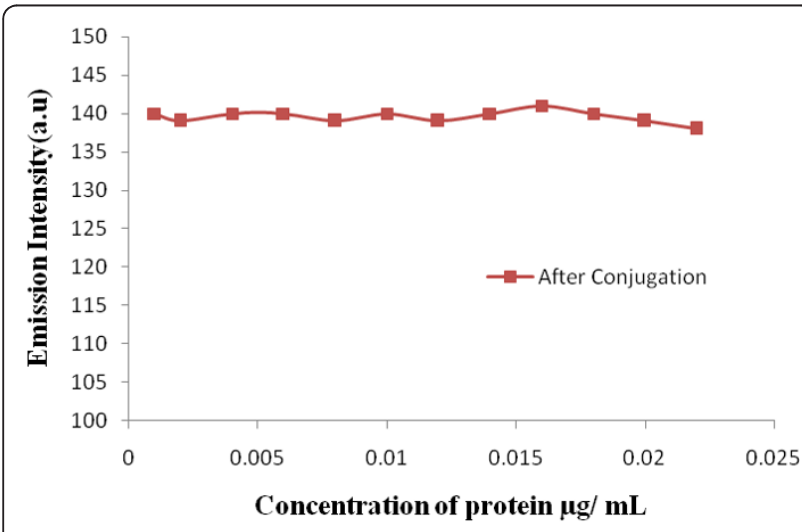

Figure 3 Fluorescence emission of fluorophore 16 before and after conjugation with protein with various amount of protein. quantum yield were carried out on Cary-Eclipse fluorescence spectrophotometer (Varian, Australia).

Absorption Spectra

Absorption spectra were measured at room temperature on a Perkin Spectronic Genesys 2 UV-Visible spectrophotometer. Absorption maxima were recorded with an accuracy of $0.5 \mathrm{~nm}$.

\section{Emission Spectra}

Emission spectra of the dyes and dye-BSA were measured at room temperature on a Varian Cary Eclipse spectrofluorometer in a standard $1 \mathrm{~cm}$ quartz cell. All dyes were excited with an excitation slit width of $5 \mathrm{~nm}$ and emission slit width of $5 \mathrm{~nm}$. The spectra were corrected. All concentrations of the fluorophores were chosen to be between 0.001 and $0.022 \mu \mathrm{M}$.

\section{General Procedure for activation of fluorophore and labelling with protein}

Protein binding reactions were carried out using coupling reagent $N$-hydroxy succinamide (NHS) and 1 ethyl-3-[3-dimethylaminopropyl] carbodiimide hydrochloride (EDC). A stock solution of $2 \mathrm{mg}$ dye was prepared in $1 \mathrm{ml} \mathrm{DMF}$ and $9 \mathrm{~mL}$ water. Various amounts of dye from the stock solution were used for protein binding at room temperature. To a solution of protein, excess of $N$-hydroxy succinamide and 1-ethyl-3-[3dimethylaminopropyl] carbodiimide hydrochloride was added and mixture shake on shaker $(150 \mathrm{rpm})$ at room temperature for $12 \mathrm{~h}$. After activation of protein, different concentration of fluorophore $\mathbf{1 6}$ in dimethyl formamide: water was added in activated protein at room temperature for binding of protein and stirred for $12 \mathrm{~h}$ (Figure 4). After $12 \mathrm{~h}$, labelled protein was separated from free fluorophore by dialysis technique (Additional file 1), labelled protein contain fluorophore was dialyzed in phosphate buffer ( $\mathrm{pH}: 7)$ to separate out unconjugated fluorophore from conjugated one. Dialyzed labelled protein was further analyzed by using fluorescence spectrophotometry to confirmed binding of fluorophore with protein bovine serum albumin.

\section{Synthesis Procedure for Compounds 1-16} Synthesis of 4-nitrophenyl acetonitrile 2

A mixture of concentrated nitric acid (specific gravity 1.42) $(138 \mathrm{~mL}, 2.15 \mathrm{~mol})$ was cooled to $0-10^{\circ} \mathrm{C}$ and 2 phenylacetonitrile 1 (50 g, $0.425 \mathrm{~mol})$ was added to it at such a rate that the temperature remained at about $10^{\circ}$ $\mathrm{C}$ and did not exceed $20^{\circ} \mathrm{C}$ during the addition. After the addition of 2-phenylacetonitrile the ice bath was removed and the reaction mixture was warmed at $40^{\circ} \mathrm{C}$ for $2 \mathrm{~h}$. Reaction mass was poured on crushed ice $(500$ g), a yellow solid separated. The solid was filtered, washed separately with ice-cold water to remove the traces of acid and dried to yield 2 .

Yield: 55 g, $79 \%$; m.p.: $114^{\circ} \mathrm{C}\left(115-116^{\circ} \mathrm{C}\right.$ lit [26]). 


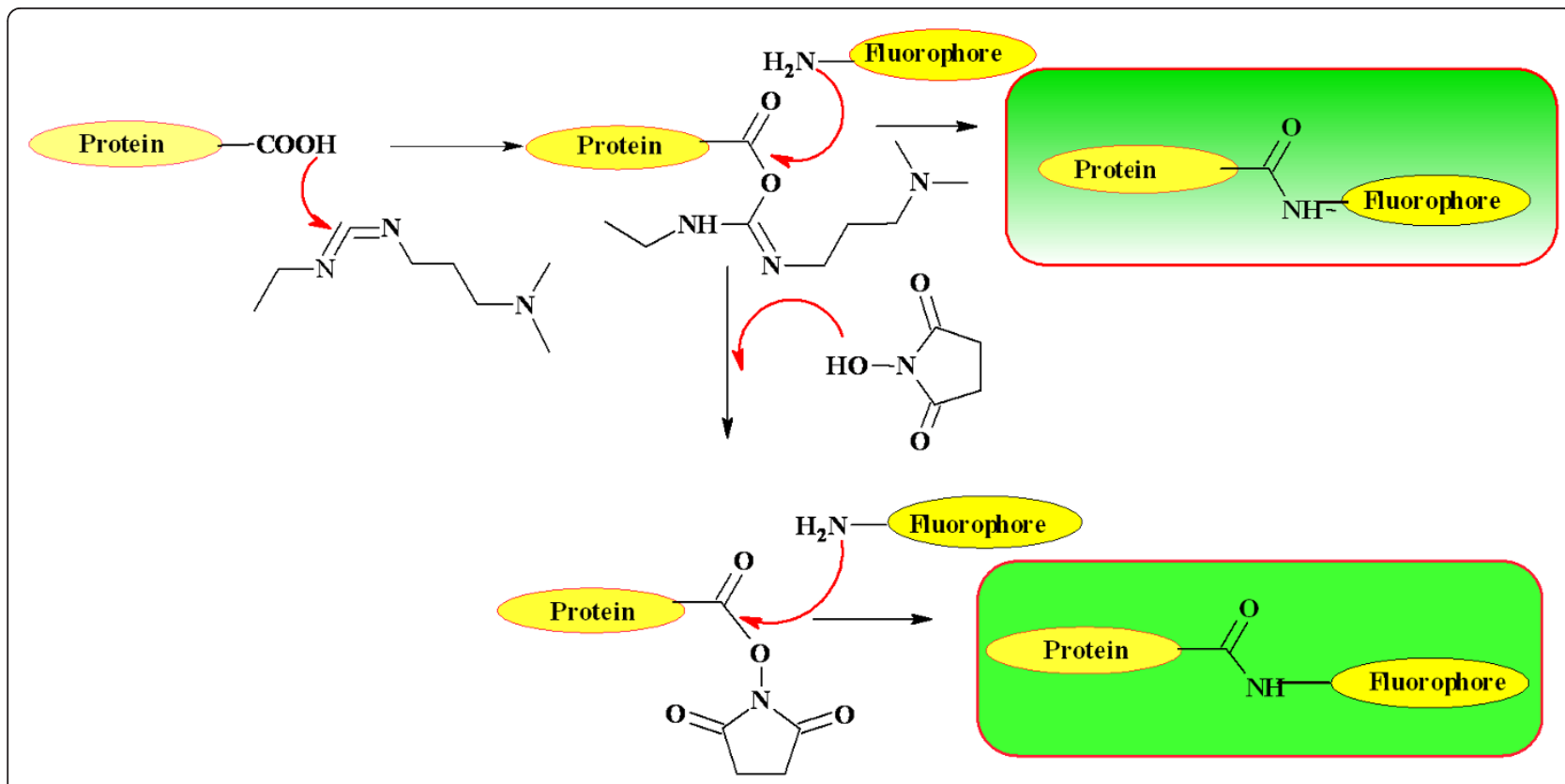

Figure 4 Activation of protein for binding.

\section{Synthesis of 4-nitrophenylacetic acid 3}

4-Nitrophenylacetonitrile 2 (50 g, $0.31 \mathrm{~mol}$ ) was added in $50 \% \mathrm{H}_{2} \mathrm{SO}_{4}(300 \mathrm{~mL})$. The reaction mixture was refluxed for $30 \mathrm{~min}$, diluted with $150 \mathrm{~mL}$ of water and cooled to $0^{\circ} \mathrm{C}$ when a colourless crystalline solid separated. The solid was filtered off, washed with ice-cold water to remove the traces of acid and dried to yield 3.

Yield: 53 g, 95\%; m.p. $150^{\circ} \mathrm{C}\left(151-152^{\circ} \mathrm{C}\right.$ lit [26]).

Synthesis of Z-2-(4'-nitrophenyl)-3-N, Ndimethylaminopropenal 4

To a vigorously stirred solution of DMF $(2.9 \mathrm{~mL})$ at $0^{\circ} \mathrm{C}$, $\mathrm{POCl}_{3}(2.8 \mathrm{~mL}, 0.030 \mathrm{~mol})$ was added dropwise. After 5 $\mathrm{min}$, the 4-nitrophenylacetic acid $7(1.81 \mathrm{~g}, 0.01 \mathrm{~mol})$ in solution in DMF $(5 \mathrm{~mL})$ was carefully added. The reaction mixture was warmed to $70^{\circ} \mathrm{C}$ for $12 \mathrm{~h}$ and then poured on crushed ice $10 \mathrm{~g}$, after neutralization by $\mathrm{K}_{2} \mathrm{CO}_{3}$, a solution of $50 \% \mathrm{NaOH}(12 \mathrm{~mL})$ was added and a precipitate was obtained upon cooling at $0^{\circ} \mathrm{C}$. The precipitate was dissolved in dichloromethane and recrystallized from diethyl ether to give yellow powder 4.

Yield: 1.43 g, $65 \%$, m.p. $131^{\circ} \mathrm{C}$. (Recrystallized from diethyl ether)

${ }^{1} \mathrm{H}$ NMR (400 MHz) $\boldsymbol{\delta}$ (ppm): $2.87\left(\mathrm{~s}, 6 \mathrm{H}, \mathrm{HN}\left(\mathrm{CH}_{3}\right)\right.$ 2), $6.97(\mathrm{~s}, 1 \mathrm{H}), 7.35-7.38(\mathrm{~d}, 2 \mathrm{H}, J=8.7 \mathrm{~Hz}, \mathrm{Ar}-\mathrm{H})$, 8.19-8.22 (d, 2H, J = 8.7 Hz, Ar-H), 9.12 (s, H, CHO).

Synthesis of Z-2-(4'-nitrophenyl)-3-hydroxypropenal 5

$33 \%$ aq. $\mathrm{NaOH}(20 \mathrm{~mL})$ was added to a solution of $Z-2$ (4'-nitrophenyl)-3- $N, N$-dimethylaminopropenal 4 (2.2 g, $0.01 \mathrm{~mol})$ in ethanol $(20 \mathrm{~mL})$ and the reaction mixture was stirred at reflux for $3 \mathrm{~h}$. Ethanol was removed under reduced pressure and the residue was cooled down with ice to give a precipitate which was filtered and washed with $\mathrm{CH}_{2} \mathrm{Cl}_{2}$, this residue was then taken in water and acidified by $6 \mathrm{~N} \mathrm{HCl}$ to give precipitate, the solid was dissolved in acetone and recrystallized from ether to give a light brown powder $\mathbf{5}$.

Yield: 1.37 g, $71 \%$, m.p.: $220^{\circ} \mathrm{C}$. (Recrystallized from diethyl ether)

${ }^{1}$ H NMR (400 MHz) $\delta$ (ppm): 7.82-7.85 (d, 2H, $J=$ $8.8 \mathrm{~Hz}, \mathrm{Ar}-\mathrm{H}), 8.18-8.23$ (d, $2 \mathrm{H}, J=8.8 \mathrm{~Hz}, \mathrm{Ar}-\mathrm{H}), 8.64$ (s, 2H, CHO), 14.45 (s, 1H, OH).

\section{Synthesis of pyrimidine-2-carboximidamide 8}

A solution of 2-cyanopyrimidine $(4.0 \mathrm{~g}, 0.038 \mathrm{~mol})$ in $7 \mathrm{~N}$ ammonia in methanol $(300 \mathrm{~mL})$ was stirred at room temperature for $48 \mathrm{~h}$. The reaction mass was allowed to a temperature of $25-30^{\circ} \mathrm{C}$ and treated with acetic acid ( 4.2 g, $0.040 \mathrm{~mol}$ ) to yield 2 -amidinopyrimidinium acetate (II). The mixture was rotary evaporated to dryness [27].

Yield: $3.5 \mathrm{~g}, 79 \%$

\section{Synthesis of dimethyl (2-methoxyphenoxy) malonate 11}

2-Methoxyphenol 9 (25 g, $0.20 \mathrm{~mol}$ ) and dimethyl chloromalonate 10 ( $37 \mathrm{~g}, 0.22 \mathrm{~mol}$ ) were added dropwise succession to a sodium methoxide solution in $150 \mathrm{~mL}$ of methanol and $4.6 \mathrm{~g}$ of sodium. The suspension was stirred at $45^{\circ} \mathrm{C}$ for $1 \mathrm{~h}$ in inert atmosphere, thereafter the methanol was distilled off. The residue was taken up in $200 \mathrm{~mL}$ of toluene and washed with water. Gave several washing of $1 \%$ sodium hydroxide solution and water until the organic phase was colourless. After drying and evaporating the solvent, the residue was distilled. There were $39.5 \mathrm{~g}$ of dimethyl (o-methoxyphenoxy) malonate 11 was obtained. 
Yield: $73 \%$

b.p. $129^{\circ} \mathrm{C}$

Synthesis of 5-(2-methoxyphenoxy)-6-hydroxy-4(3H)-

pyrimidinone 12

Pyrimidine-2-carboximidamide acetate 8 (5.5 g, 0.045 mol) prepared from 2-chloropyrimidine and dimethyl (2-methoxyphenoxy) malonate 11 (2.7 g, $0.01 \mathrm{~mol})$ was heated in acetic acid for $5 \mathrm{~h}$, After completion of reaction, reaction mass poured in ice-cold water, buff white colored product separated and it was recrystallized from ethanol to gave pure $\mathbf{1 2}$

Yield: $76 \%$

m.p.: $226-228^{\circ} \mathrm{C}$.

FT-IR (KBr) v max.: $1176(-\mathrm{O}-), 1386,1563(\mathrm{C}=\mathrm{C})$, $1723(\mathrm{C}=\mathrm{O}), 3271(\mathrm{NH}) \mathrm{cm}^{-1}$.

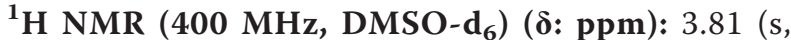
$\left.3 \mathrm{H},-\mathrm{OCH}_{3}\right), 6.67$ (dd, $\left.1 \mathrm{H}, J=1.5,6.4 \mathrm{~Hz}, \mathrm{Ar}-\mathrm{H}\right), 6.77$ $(\mathrm{d}, 1 \mathrm{H}, J=1.5,5.9 \mathrm{~Hz}, \mathrm{Ar}-\mathrm{H}), 6.91(\mathrm{~d}, 1 \mathrm{H}, J=1.5,6.0$ $\mathrm{Hz}, \mathrm{Ar}-\mathrm{H}$ ), 7.00 (dd, $1 \mathrm{H}, J=1.5,6.4 \mathrm{~Hz}, \mathrm{Ar}-\mathrm{H}), 7.70$ $(\mathrm{dd}, 1 \mathrm{H}, J=6.0 \mathrm{~Hz}, \mathrm{Ar}-\mathrm{H}), 9.01(\mathrm{~m}, 1 \mathrm{H}, J=5.0 \mathrm{~Hz}, \mathrm{Ar}-$ $\mathrm{H}), 12.39$ (s, 1H, NH).

${ }^{13}$ C NMR (100 MHz, DMSO-d 6 ,) (ס: ppm): 55.8, $112.9,113.3,120.6,121.3,122.0123 .1,146.6,148.5$, 149.4, 156.9, 158.2, 160.1 .

Mass: $\mathrm{m} / \mathrm{e}=313.1(\mathrm{M}+1)$.

Synthesis of 4, 6-dichloro-5(2-methoxyphenoxy)-2, 2'bipyridine 13

A mixture of 5-(2-methoxyphenoxy)-6-hydroxy-4 (3H)pyrimidinone 12 (150.0 g, $0.48 \mathrm{~mol}$ ) and phosphorus oxychloride (290 g, $176 \mathrm{~mL} 1.89 \mathrm{~mol}$ ) was heated to $90^{\circ} \mathrm{C}$. After the vigorous gas evolution subsided, the pot temperature was increased to $105^{\circ} \mathrm{C}$ and maintained for $5 \mathrm{~h}$. The mixture was cooled to $80-90^{\circ} \mathrm{C}$, diluted with $225 \mathrm{~mL}$ of toluene and then added to a mixture of $675 \mathrm{~mL}$ of toluene and $525 \mathrm{~mL}$ of water over $30 \mathrm{~min}$. Aqueous sodium hydroxide $(400 \mathrm{~mL}$ of $30 \%$ ) was added at $70-80^{\circ} \mathrm{C}$, and then the layers were separated. Toluene layer was washed with $500 \mathrm{~mL}$ of water containing $10 \mathrm{~mL}$ of $30 \%$ aqueous $\mathrm{NaOH}$, toluene layer was concentrate to dryness to afford 220 g of buff white product 13 .

m.p.: $79^{\circ} \mathrm{C}$.

Yield: $83 \%$

FT-IR (KBr): 751, 811, 1112, 1253, 1386, 1499, 1563 $\mathrm{cm}^{-1}$.

${ }^{1}$ H NMR (400 MHz, DMSO-d 6 ) (ס: ppm): 3.84 (s, $\left.3 \mathrm{H},-\mathrm{OCH}_{3}\right), 6.83(\mathrm{~d}, 1 \mathrm{H}, J=1.8 \mathrm{~Hz}, \mathrm{Ar}-\mathrm{H}), 6.94-6.96(\mathrm{t}$, $1 \mathrm{H}, J=1.5 \mathrm{~Hz}$, Ar H), $7.15-7.18(\mathrm{~d}, 2 \mathrm{H}, J=1.5,5.5$ $\mathrm{Hz}, \operatorname{Ar}-\mathrm{H}), 7.68-7.72$ (d, $1 \mathrm{H}, J=5.5 \mathrm{~Hz}, \mathrm{Ar} \mathrm{H}), 9.05$ (m, $1 \mathrm{H}, J=5.5 \mathrm{~Hz})$.

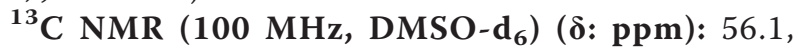
113.6, 115.8, 121.0, 122.6, 124.7, 143.5, 144.7, 148.7, 154.7, 157.0, 158.3, 159.9.

Mass: m/e 351.1(M+2).
Synthesis of 4, 6-dihydrazinyl-5-(2-methoxyphenoxy)-2, 2'bipyrimidine 14

A mixture of 4, 6-dichloro-5(2-methoxyphenoxy)-2, 2'bipyridine 13 ( $2 \mathrm{~g}, 0.0067 \mathrm{~mol})$, hydrazine hydrate $(0.65$ g, $0.013 \mathrm{~mol})$ and ethanol $(20 \mathrm{~mL})$ was refluxed for $1 \mathrm{~h}$, cooled, filtered and washed with ethanol to yield $\mathbf{1 4}$.

Yield: $92 \%$

m.p.: $>300^{\circ} \mathrm{C}$.

FT-IR (KBr) v max: 750, 831, 1110, 1256, 1396, 1500, 1560, 2904, 3306, $3396\left(-\mathrm{NH}_{2}\right) \mathrm{cm}^{-1}$.

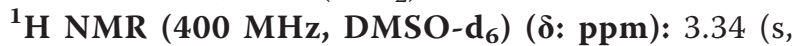
$\left.3 \mathrm{H},-\mathrm{OCH}_{3}\right), 5.36(\mathrm{~s}, 2 \mathrm{H}, \mathrm{NH}), 6.60-6.63(\mathrm{~d}, 1 \mathrm{H}, J=8.4$ $\mathrm{Hz}, \operatorname{Ar} \mathrm{H}), 7.34-7.40$ (d, $4 \mathrm{H},-\mathrm{NH}_{2}$ ), 7.48-7.50 (d, $2 \mathrm{H}, J=$ 7.4 Hz, Ar-H), 7.72-7.75 (d, 2H, $J=8.8 \mathrm{~Hz}$, Ar H).

Mass: m/e 341(M + 1).

Synthesis of 5-(2-methoxyphenoxy)-4, 6-bis(3-)4nitrophenyl)-1H-pyrazole-1-yl)-2, 2'-bipyrimidine 15

A mixture of 4, 6-dihydrazinyl-5-(2-methoxyphenoxy)-2, 2'-bipyrimidine 14 (3.86 g, $0.02 \mathrm{~mol}), Z$-2-(4'-nitrophenyl)-3-hydroxypropenals 5 (2.98 g, $0.01 \mathrm{~mol}$ ) and ethanol $(40 \mathrm{~mL})$ was refluxed for $3 \mathrm{~h}$, cooled and poured into ice water $(100 \mathrm{~mL})$ to yield crude 15 which was crystallized from ethanol to yield pure $\mathbf{1 5}$.

Yield: $67 \%$

m.p.: $>300^{\circ} \mathrm{C}$

FT-IR (KBr): 748, 852, 959, 1100, 1173, 1254, 1333 $\left(-\mathrm{NO}_{2}\right), 1393,1500,1529,1601 \mathrm{~cm}^{-1}$.

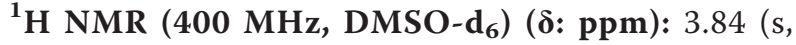
$\left.3 \mathrm{H},-\mathrm{OCH}_{3}\right), 6.77-6.88(\mathrm{t}, 2 \mathrm{H}, J=7.2,7.8 \mathrm{~Hz}, \mathrm{Ar} \mathrm{H})$, $6.88(\mathrm{~d}, 1 \mathrm{H}, J=8.2 \mathrm{~Hz}), 7.01(\mathrm{t}, 2 \mathrm{H}, J=7.8 \mathrm{~Hz}), 7.09(\mathrm{~d}$, $1 \mathrm{H}, J=7.8 \mathrm{~Hz}), 7.74(\mathrm{t}, 1 \mathrm{H}, J=5.0 \mathrm{~Hz}), 8.00(\mathrm{~d}, 3 \mathrm{H}, J=$ $8.7 \mathrm{~Hz}$ ), 8.24-8.27 (d, 3H, J = 8.8 Hz, Ar-H), 8.47 (s, 2H, Ar-H), 9.09-9.11 (d, 1H, J = 4.8 Hz, Ar-H), 9.19 (s, $1 \mathrm{H}$, Ar-H).

Mass: $\mathrm{m} / \mathrm{e}=655(\mathrm{M}+1)$.

Synthesis of 4, 4'-(1, 1'-(5-(2-methoxyphenoxy)-[2, 2'-

bipyrimidine]-4, 6-diyl)bis(1H-pyrazole-3, 1-diyl)) dianiline 16 Palladium-carbon catalyst (0.036 g) (10\%) was added portion-wise during 5-10 min to a hot solution of $\mathbf{1 5}$ $(2.0 \mathrm{~g}, 0.003 \mathrm{~mol})$ in ethanol $(50 \mathrm{~mL})$ containing hydrazine hydrate $(1.16 \mathrm{~g} 0.023 \mathrm{~mol})$. The mixture was heated under reflux for $1 \mathrm{~h}$. The hot solution was filtered through a Whatman paper to remove Pd and further filtrate was filtered through silica gel (10 g) and the solvent was evaporated to offered pure product $\mathbf{1 6}$ and recrystallized from ethanol.

Yield: $83 \%$

m.p.: $>300^{\circ} \mathrm{C}$.

FT-IR (KBr): 749, 852, 9017, 1109, 1163, 1249, 1496, 1561, 2966, $3174\left(-\mathrm{NH}_{2}\right) \mathrm{cm}^{-1}$.

${ }^{1} \mathrm{H}$ NMR (400 MHz, DMSO $\mathrm{d}_{6}, \mathrm{D}_{2} \mathrm{O}$ Exchange) ( $\delta$ : ppm): 3.85 (s, $\left.3 \mathrm{H},-\mathrm{OCH}_{3}\right), 6.57-6.59$ (d, $2 \mathrm{H}, J=7.8 \mathrm{~Hz}$, Ar-H), 6.69-6.71 (t, 2H, $J=6.3 \mathrm{~Hz}, \mathrm{Ar}-\mathrm{H}), 6.90-6.92(\mathrm{t}$, $2 \mathrm{H}, J=7.3 \mathrm{~Hz}, \mathrm{Ar}-\mathrm{H}) 7.04(\mathrm{~d}, 1 \mathrm{H}, J=7.8 \mathrm{~Hz}, \mathrm{Ar}-\mathrm{H})$, 
7.65-7.68 (t, $1 \mathrm{H}, J=5.0 \mathrm{~Hz}, \mathrm{Ar}-\mathrm{H}), 7.81-7.89$ (dd, 4H, $J$ $=8.8, \mathrm{Ar}-\mathrm{H}), 8.19-8.27(\mathrm{dd}, 4 \mathrm{H}, J=3.4,5.4,6.8 \mathrm{~Hz}, \mathrm{Ar}-$ $\mathrm{H}), 8.91$ (d, 1H), 9.02-9.03 (d, 2H, Ar-H).

Mass: $\mathrm{m} / \mathrm{e}=595.6(\mathrm{M}+1)$.

Elemental Analysis: Expected: C: 66.66; H: 4.41; N: 23.56; O: 5.38; Found: C: 66.63; H: 4.40, N: 23.57

\section{Conclusion}

In summary, synthesized fluorescent pyrazole bipyrimidine has very good binding interaction with bovine serum albumin. The method is based on the direct fluorescence detection of protein-labelled with triazine fluorophores after dialysis. The more evident fluorescent signal was obtained at very little concentration of fluorophore and easily detectable in near visible region which indicates an important application for this compound as fluorophores for protein assay.

\section{Additional material}

Additional file 1: Graph for quantum yield calculation and dialysis of conjugated protein. Supplementary figures.

\section{Acknowledgements}

Authors are thankful to Indian Institute of Technology, Mumbai for NMR and Mass spectral analysis.

\section{Authors' contributions}

VSP contributed for synthesis and spectral analysis under the guidance NS; VSP and VSP contributed bioconjugation study and photophysical study under the guidance NS. All the authors read and approved the final manuscript.

\section{Competing interests}

The authors declare that they have no competing interests.

Received: 27 September 2011 Accepted: 9 November 2011 Published: 9 November 2011

\section{References}

1. Schrader T, Koch S: Artificial protein sensors. Mol Bio Syst 2007, 3:241-248.

2. Fields S: Proteomics in genomel. Science 2001, 291:1221-1224.

3. Aebersold R, Mann M: Mass spectrometry-based proteomics. Nature 2003, 422:198-207

4. Selkoe DJ: Folding proteins in fatal ways. Nature 2003, 426:900-904

5. Johnson CJ, Zhukovsky N, Cass AE, Nagy JM: Nanotechnology and molecular diagnostics. Proteomics 2008, 8:715-773.

6. Kodadek T: Protein microarrays: prospects and problems. Chem Biol 2001, 8:105-115

7. Benito-Pena E, Moreno-Bondi MC, Orellana G, Maquieira K, Amerongen AV Development of a novel and automated fluorescent immunoassay for the analysis of beta- lactam antibiotics. J Agric Food Chem 2005, 53:6635-6642.

8. Wang J, Liu GD, Engelhard MH, Lin YH: Simultaneous detection of dual proteins using quantum dots. Anal Chem 2006, 78:6974-6979.

9. Li T, Guo LP, Wang ZX: Highly sensitive immunoassay based on Raman reporter-labeled immuno-Au aggregates and SERS-active immune substrate. Biosens Bioelectron 2008, 23:1125-1130.

10. Jie GF, Zhang JJ, Wang DC, Cheng C, Chen HY, Zhu J: Electrochemiluminescence immunosensor based on CdSe Nanocomposites. J Anal Chem 2008, 80:4033-4039.
11. Soman CP, Giorgio TD: Quantum dot self-assembly for protein detection with sub-picomolar sensitivity. Langmuir 2008, 24:4399-4404.

12. Wan $L S$, Ke BB, Xu ZK: Electrospun nanofibrous membranes filled with carbon nanotubes for redox enzyme immobilization. Enzyme Microb Technol 2008, 42:332-339.

13. Fuller $R$, Moroz $L$, Gillette $R$, Sweedler J: Single-cell analyses of nitrergic neurons in simple nervous systems. Neuron 1998, 20:173-181.

14. Okerberg E: Shear Neuropeptide analysis using capillary electrophoresis with multiphoton-excited intrinsic fluorescence detection. J Anal Biochem 2001, 292:311-313.

15. Birch D: Multiphoton excited fluorescence spectroscopy of biomolecular systems. Spectrosc Acta A 2001, 57:2313-2336.

16. Sun W, Gee K, Haugland R: Synthesis of novel fluorinated coumarins: Excellent UV-light excitable fluorescent dyes. Bioorg Med Chem Lett 1998, 8:3107-3110

17. Zhang $X$, Neamati N, Lee $Y$, Orr A, Brown R, Whitaker N, Pommier $Y$ : Arylisothiocyanate-containing esters of caffeic acid designed as affinity ligands for HIV-1 integrase. J Bioorg Med Chem 2001, 2:1649-1657.

18. DiCesare N, Lakowicz J: Evaluation of Two Synthetic Glucose Probes for Fluorescence-Lifetime-Based Sensing. Anal Biochem 2001, 294:154-160.

19. Sartor G, Pagani R, Ferrari E, Sorbi R, Cavaggioni A, Cavatorta P, Spisni A Determining the binding capability of the mouse major urinary proteins using 2-naphthol as a fluorescent probe. Anal Biochem 2001, 292:69-75.

20. Kessler M, Wolfbeis O: Laser-induced fluorometric determination of albumin using longwave absorbing molecular probes. Anal Biochem 1992, 200:254-259.

21. Haugland RP: Handbook of fluorescent probes and research chemicals Eugene, Oreg: Molecular Probes, Inc; 1996, 679.

22. Sekar N, Raut R, Umape P: Near Infrared absorbing iron-complexed colorants for photovoltaic applications. Material Science and Engineering $B$ 2010, 168:259-262.

23. Padalkar V, Patil V, Phatangare K, Gupta V, Umape P, Sekar N: Synthesis of nanodispersible 6-aryl-2, 4-diamino-1, 3, 5-triazine and its derivatives. Material Science and Engineering B 2010, 170:77-87.

24. Gupta V, Padalkar V, Patil V, Phatangare K, Umape P, Sekar N: The synthesis and photo-physical properties of extended styryl fluorescent derivatives of $N$-ethyl carbazole. Dyes and Pigments 2011, 88:378-384.

25. Williams A, Winfield S, Miller J: Relative fluorescence quantum yields sing a computer controlled luminescence spectrometer. Analyst 1983, 108:1067-1071.

26. Sekar N: Synthesis of Heterocyclic Colorants Ph. D thesis, University of Bombay, Mumbai, Maharashtra; 1987.

27. Peter JH, Hiralal NK, Brad SD, Martin RG, Mark AB, Karl AG: Research and development of a second-generation process for bosentan, an endothelin receptor antagonist. Organic process research \& development 2002, 6:120-124.

doi:10.1186/1752-153X-5-72

Cite this article as: Padalkar et al:: Synthesis and characterization of novel 2, 2'-bipyrimidine fluorescent derivative for protein binding. Chemistry Central Journal 2011 5:72

\section{Publish with ChemistryCentral and every scientist can read your work free of charge \\ “Open access provides opportunities to our colleagues in other parts of the globe, by allowing anyone to view the content free of charge." W. Jeffery Hurst, The Hershey Company. \\ - available free of charge to the entire scientific community \\ - peer reviewed and published immediately upon acceptance \\ - cited in PubMed and archived on PubMed Central \\ - yours - you keep the copyright \\ Submit your manuscript here: \\ http://www.chemistrycentral.com/manuscript/<smiles>c1ccccc1</smiles> ChemistryCentral}

